\title{
ROLE OF BREAKFAST IN NUTRIENT INTAKE OF PRESCHOOL CHILDREN
}

\author{
Akkavva Wadakappanavar. $\mathrm{S}^{1} \&$ Pushpa Bharati ${ }^{2}$ \\ ${ }^{1}$ Post Graduate Student, Department of Food Science and Nutrition, Rural Home Science College \\ University of Agricultural Sciences, Dharwad, Karnataka, India \\ ${ }^{2}$ Professor, Department of Food Science and Nutrition, Rural Home Science College \\ University of Agricultural Sciences, Dharwad, Karnataka, India
}

\begin{abstract}
Breakfast is among the important and first meal, which in early morning satisfies the nutritional needs and increases mental work load ability. Eating breakfast improves the overall quality and nutrient intake of the diet. Intake of protein was 5.25 (rural) and $5.56 \mathrm{~g} / \mathrm{d}$ (urban) and could meet 104.48 per cent and 110.65 per cent of one fourth RDA, respectively. Except visible fat, energy and sodium the intake of all nutrients was higher in breakfast consumers compared to skippers with the adequacy of 82.12 per cent of fat and 61.63 per cent of energy. There was significant difference between consumers and skippers in the intake of protein (19.82 vs. $15.36 \mathrm{~g} / \mathrm{d}$ and $98.61 \mathrm{vs} .76 .42 \%$ adequate), visible fat (16.37 vs. $20.53 \mathrm{~g} / \mathrm{d}$ and $65.48 \mathrm{vs} .82 .12 \%$ adequate) and sodium (99.85 vs. $175.58 \mathrm{mg} / \mathrm{d})$.There was significant difference in the intake of pulses, fruits, visible fats and eggs between breakfast consumers and skippers. Majority of rural (81.67\%) and urban (75.0\%) children could not meet one fourth of Recommended Dietary Allowances (RDA) for energy while, only few children in rural (18.33\%) and urban (25.0\%) one fourth of RDA could be met.
\end{abstract}

KEYWORDS: Breakfast, Nutrient Intake \& Preschool Children

Received: Apr 27, 2017; Accepted: May 31, 2017; Published: Jun 13, 2017; Paper Id.: IJESRJUN20179

\section{INTRODUCTION}

Breakfast is considered an important meal of the day (Marika, 2003). It is described as the first meal, which breaks the fast that had been on for over twelve to fourteen hours (Wayonet al., 1997). It is comprised of food or beverage from at least one food group, and may be consumed at any location (Dwyer. 2014). Breakfast should provide 25 per cent of the daily nutrient requirement to an individual (Gibson and O'Sullivan, 1995). It is a fact that gap between dinner and breakfast is so high that an individual is really starving. Without a breakfast there is the possibility of low blood glucose levels (hypoglycemia) and low metabolic rate, irritability and fatigue (Marika, 2003). The quality of the breakfast is important as the nutritional status of a child can be affected as well as the physical and mental growth, health and general well-being of the child. Breakfast is important factor in the health of children, as the body is low in energy reserve and there is a need for frequent supply of energy needed for the day.

Skipping breakfast has become the norm in modern day. India, because of changes in family life style, When this happens largely among children, it can result in their suboptimal growth and development a factor important to the future human resource development of the country (Chitra and reddy, 2006). It is estimated that several children attend school daily without having eaten any breakfast and many more consume an inadequate breakfast (Gross et al., 2004). Skipping breakfast can affect children's physical and mental development (Sethi M, Dangwal, 2001). Skipping breakfast may hinder child growth because the body is forced to call upon stores of 
protein to meet energy requirements. Eating breakfast improves the overall quality and nutrient intake of the diet. Several investigators have suggested that omission of breakfast and/or consumption of an inadequate breakfast may be factors contributing to dietary inadequacies, and that the accompanying nutrition al losses are rarely made up by other meals during the remainder of the day (Colic Baric and Satalic et al., 2003). The dietary intake patterns of children have been a special concern, since it was found that eating patterns formed in early life are likely to persist into adulthood.

Nutrition of preschool child is of paramount importance, because foundation for life time health, strength, and intellectual abilities are laid down during this period. Preschool age is in between stages of infancy and school age, when rapid physical, mental and emotional development takes place. Ten per cent of physical growth and 80 per cent of mental growth are believed to take place from conception to 6 years of age. So, childhood diets need to be paid more attention to improve health of children, so that health of nation is improved. But, food available to many children in developing nations is neither adequate nor suitable for building resistance to diseases, mental and physical development. So, a large number of pre-school children suffer from growth retardation of various degrees and nutritional deficiency (Manu and Khetarpaul, 2006). Hence, the study has been undertaken to assess the contribution of nutrients from breakfast.

\section{METHODS}

The study was conducted in rural and urban areas of Dharwadtaluk, Karnataka, India during 2013-2015. A total of 13 anganwadis were contacted, total of 565 preschool children in the age group of 5-6 years attending anganwadis were selected, randomly. Information on breakfast consumption pattern of preschool children was obtained by interviewing the mothers of the children, personally with the use of structured validated questionnaire. Breakfast consumers and skippers were classified as always, often, sometimes and rarely (Liu et al., 2013), according to the regularity of breakfast consumed by the children. With the help of standardized cups, amount of breakfast was recorded to estimate the food and nutrient intake. Information on cooked food was converted to raw ingredients. The intake or nutritive value of the breakfast item consumed was computed using software, Annapurna VAR 3 developed by M.R. Chandrasekhar of Bangalore. The data were analysed using the statistical package for social science (SPSS). Descriptive statistics (percentages, ANOVAs two factor, Independent $t$ test), were used to analyze the data.

\section{RESULTS AND DISCUSSIONS}

Mean nutrient intake through breakfast and its contribution to nutrient intake computed is furnished in "Table 1" and adequacy is depicted in "figure 1". It can be visualized from the Table and Figure that the contribution of breakfast to the intake of major nutrients among all the preschool children studied was less than one third or one fourth of the recommended dietary allowances except protein in both rural $(104.48 \%)$ and urban $(110.65 \%)$ locality.

Energy intake of rural children $(253 \mathrm{Kcal})$ was slightly higher than urban children $(247 \mathrm{Kcal})$ with the adequacy of 75.07 and 73.29 per cent, respectively. Intake of protein was 5.25 (rural) and $5.56 \mathrm{~g} / \mathrm{d}$ (urban) and could meet 104.48 per cent and 110.65 per cent of one fourth RDA, respectively. The contribution of breakfast to intake of minerals like calcium, iron and zinc was less than one fourth RDA. But, that of magnesium was higher than one fourth or one third RDA. Sodium contribution was higher in urban while potassium was higher in rural than their counterparts.

"Figure 2" represents distribution of preschool children based on breakfast consumption to meet one fourth RDA. Results indicated that majority of rural $(81.67 \%)$ and urban $(75.0 \%)$ children could not meet one fourth of Recommended Dietary Allowances (RDA) for energy while, only few children in rural (18.33\%) and urban (25.0\%) one fourth of RDA 
could be met. Irrespective of locality, nearly 80 per cent of children did not meet one fourth of RDA for energy (78.33), but only 21.67 percent of children could meet RDA for energy. More than 50 per cent of rural and urban children (51.69 and $55.84 \%$, respectively) met one fourth RDA for protein. Irrespective of locality, more than 50 per cent of children (55.84 $\%$ ) met the protein requirement while, 44.16 per cent could not meet.

Mean nutrient intake through breakfast and its contribution to nutrient intake computed is furnished in "Table 1" and adequacy is depicted in "figure 1". Contribution of breakfast to the intake of major nutrients among all the preschool children studied was less than one third or one fourth of the recommended dietary allowances, except protein in both rural $(104.48 \%)$ and urban $(110.65 \%)$ locality.

Energy intake of rural children $(253 \mathrm{Kcal})$ was slightly higher than urban children $(247 \mathrm{Kcal})$ with the adequacy of 75.07 and 73.29 per cent, respectively. Intake of protein was 5.25 (rural) and $5.56 \mathrm{~g} / \mathrm{d}$ (urban) and could meet 104.48 per cent and 110.65 per cent of one fourth RDA, respectively. The intake of fat among rural and urban children was equal (6.12\% each), meeting the 97.92 per cent of one fourth ICMR recommendations. Breakfast consumption helps to increase the intake of nutrients. In the present study, rural children ingested slightly higher (43.72 $\mathrm{g})$ amount of carbohydrates than the urban (42.08g), which probably has contributed to slight increase in the energy intake of rural (253 K cal) than urban (247 Kcal) children ("Table 1"). Similar results of higher carbohydrate intake by rural children were noted by Toresset al., 2007. Mean calorific intake by breakfast was around 250 Kcal meeting 74.18 per cent of one fourth RDA ("Figure 1"), which was lower than the value reported by Torres et al, (2007) in Spain. This difference can be attributed to the variation in breakfast items consumed, milk, cocoa and sugar, biscuits, breakfast cereals or bread in Spain as against dosa, upma, biscuits in present study. Also, it may because to preschool children consume breakfast not in sufficient quantity to meet one fourth of the RDA.

"Table 2" shows the daily intake of the foods by the preschool children according to breakfast behavior. There was significant difference in the intake of pulses, fruits, visible fats and eggs between breakfast consumers and skippers. Breakfast consumers took significantly higher amount of pulses $(14.76 \mathrm{~g} / \mathrm{d})$, fruits (30 $\mathrm{g} / \mathrm{d})$ and milk and milk products $(102.09 \mathrm{ml} / \mathrm{d})$ and lower amounts of visible fat $(7.66 \mathrm{~g} / \mathrm{d})$ and eggs $(27.69 \mathrm{~g} / \mathrm{d})$ compared to skippers (pulses $8.66 \mathrm{~g} / \mathrm{d}$, fruits 0.0 , milk and milk products $67.69 \mathrm{ml} / \mathrm{d}$, visible fats $11.50 \mathrm{~g} / \mathrm{d}$ and eggs $27.69 \mathrm{~g} / \mathrm{d}$ ) and these values are statistically significant. The intake of cereals (244.92g), pulses (44.94g), GLVs $(6.07 \mathrm{~g})$, roots and tubers $(54.14 \mathrm{~g})$, The intake of milk and milk products and sugars was higher in breakfast consumers $(102.09 \mathrm{ml} / \mathrm{d}$ and $9.43 \mathrm{~g} / \mathrm{d}$, respectively) compared to skippers $(67.69 \mathrm{ml} / \mathrm{d}$ and $7.69 \mathrm{~g} / \mathrm{d}$, respectively) and the difference was statistically on par.

Daily intake of nutrients by the breakfast consumers and skippers is revealed in "Table 3" and "Figure 3". Except visible fat, energy and sodium the intake of all nutrients was higher in breakfast consumers compared to skippers with the adequacy of 82.12 per cent of fat and 61.63 per cent of energy. There was significant difference between consumers and skippers in the intake of protein (19.82 vs. $15.36 \mathrm{~g} / \mathrm{d}$ and 98.61 vs. $76.42 \%$ adequate), visible fat (16.37 vs. $20.53 \mathrm{~g} / \mathrm{d}$ and 65.48 vs. $82.12 \%$ adequate) and sodium (99.85 vs. $175.58 \mathrm{mg} / \mathrm{d})$. The evidence supporting the relationship between breakfast consumption and body weight is growing (Utter et al., 2007). Children skipping breakfast tend to be significantly heavier than those, who consume breakfast regularly. This might be due to the reason that breakfast skippers had consumed higher amounts of visible fat and eggs (“Table 3"). In the present study, intake of pulses, fruits and milk was significantly higher among those who consumed breakfast than skippers. Though milk intake was $35 \mathrm{ml}$ higher among consumers, it was not significant (“Table 2"). This higher consumption has resulted in increased intake of fat and energy (Table 20), 
which leads to higher weight among skippers. This can be attributed to the fact that children who are not regular in breakfast consumption are less likely to regularly eat lunch or dinner and are significantly more likely to consume high fat, empty calorie snack foods, mostly between the meals, thus resulting in an increase in the body weight. Many cross sectional studies have documented relationship between skipping breakfast and higher BMI (Dwayeret al., 2001, Affinities al., 2005, Sjoberget al., 2003, Keski-Rahkonenet al., 2003, Dea and Caputi, 2001 and Andersen et al., 2005). Berkley and colleagues (2003) demonstrated that normal-weight children, who never ate breakfast gained more weight during a year compared to peers, who usually ate breakfast, although this relationship was not found among overweight children.

\section{CONCLUSIONS}

Breakfast should provide 25 per cent of the daily nutrient requirement to an individual (Gibson and O'Sullivan, 1995). The quality of the breakfast is important, as the nutritional status of a child can be affected as well as the physical and mental growth, health and general well-being of the child. Contribution of breakfast to the intake of major nutrients among all the preschool children studied was less than one third or one fourth of the recommended dietary allowances, except protein in both rural $(104.48 \%)$ and urban $(110.65 \%)$ locality. Energy intake of rural children (253 Kcal) was slightly higher than urban children $(247 \mathrm{Kcal})$ with the adequacy of 75.07 and 73.29 per cent, respectively. Intake of protein was 5.25 (rural) and $5.56 \mathrm{~g} / \mathrm{d}$ (urban) and could meet 104.48 per cent and 110.65 per cent of one fourth RDA, respectively. There was significant difference between consumers and skippers in the intake of protein (19.82 vs. $15.36 \mathrm{~g} / \mathrm{d}$ and 98.61 vs. $76.42 \%$ adequate), visible fat (16.37 vs. $20.53 \mathrm{~g} / \mathrm{d}$ and 65.48 vs. $82.12 \%$ adequate) and sodium (99.85 vs. $175.58 \mathrm{mg} / \mathrm{d})$.

\section{REFERENCES}

1. Affenito, S. G., Thompson, D. R., Barton, B. A., Franco, D. L., Daniels, S. R., Obarzanek, E., Schreiber, G. B. and StriegelMoore, R. H., (2005). Breakfast consumption by African American and white adolescent girls correlates positively with calcium and fiber intake and negatively with body mass index. Journal of American Dietetic Association, 105(6), 938-945

2. Andersen, L. F., Lillegaard, I.T., Over by, N., Lytle, L., Klepp, K. I. and Johansson, L., (2005). Overweight and obesity among Norwegian schoolchildren: Changes from 1993 to 2000. Scandinavian Journal of Public Health, 33 (1), 99-106

3. Berkey, C. S., Rocket, H. R., Gillman, M. W., Field, A.E., \&Colditz, G. A., (2003). Longitudinal study of skipping breakfast and weight change in adolescents. International Journal of Obesity. 27, 1258-1266

4. Chitra, U. and Reddy, R., (2006).The role of breakfast in nutrient intake of urban school children. Public Health Nutrition., $10(1), 55-58$

5. Colic Baric, I. \&Satalic Z (2003). Breakfast food patterns among urban and rural Croatian schoolchildren. Nutrition and Health, 17(1), 29-41

6. Dea, O. J. A. and Caputi, P., (2001). Association between socioeconomic status, weight, age and gender, and the body image and weight control practices of 6- to 19-yearold children and adolescents. Health Education Research., 16(3),521-532

7. Dwyer, J.T., (2014). Defining Nutritious Breakfasts and Their Benefits Johanna. Journal of Academy Nutrition and Dietetetics $114(3), 12 s 4-s 7$

8. Gibson, A. and O'Sullivan, L., (1995). Breakfast cereal consumption patterns and nutrient intakes in British school children. Journal of Royal Society Health, 115 (6), $366-370$ 
9. Gross, S. M., Bronner, Y., Welch, C., Dewberry-Moore, N., Paige, D. M., (2004).Breakfast and lunch meal skipping patterns among fourth-grade children from selected public schools in urban, suburban and rural Maryland. Journal of the American Dietetic Association, 104(3), 420-3

10. Keski Rahkonen, A., Kaprio, J., Rissanen, A., Virkkunen and Rose, R. J., (2003).Breakfast skipping and health compromising behaviors in adolescents and adults European. Journal of clinical nutrition. 57,842-853

11. Liu, J., McCauley, L., Compher, C., Yan, C., Shen, X., Needleman, H., \& Pinto-Martin, J. (2013). Regular Breakfast and Blood Lead Levels among Preschool Children. Environmental Health. 10(28), 1-8

12. Liu, J., McCauley, L., Compher, C., Yan, C., Shen, X., Needleman, H. and Pinto-Martin, J., (2013). Regular Breakfast and Blood Lead Levels among Preschool Children. Environmental Health. 10(28),1-8

13. Manu and Khetarpaul, N., (2006).Gender differences in food consumption pattern and nutrient intake of Indian pre-school children (3-4 years) in Haryana State. Journal of Nutrition and Health. 18(2), 141-149

14. Marika, S., (2003).Breakfast to learning. Journal of American Dietetic Association. 51(2),8 - 21

15. Sethi, M. and Dangwal, R., (2001). Breakfast eating patterns of school children and their impact on nutritional status. Nutrition Foundation of India. 10,108-114

16. Sethi, M., \&Dangwal, R., (2001).Breakfast Eating Patterns of School Children and their Impact on Nutritional Status.CRNSS Update Series No. 10, Nutrition in Disease Management. New Delhi: The Nutrition Foundation of India, 8-16

17. Sjoberg, A., Hallberg, L., Hoglund, D. and Hulthen, L., (2003). Meal pattern, food choice, nutrient intake and lifestyle factors in the Goteborg adolescence study. European. Journal of clinical nutrition, 57, 1569-1647

18. Torres, M. D., Carmona, I., Campillo, C., Pérezy, G. \&Campillo, J. E., (2007).Breakfast, plasma glucose and $\beta$ hydroxybutyrate, body mass index and academic performance in children from Extremadura, Spain. Nutrition Hospital. 22(4), 487-490

19. Utter Jennifer, Robert Scraggy., Mhurchu, C. \& David Schaaf, (2007). At home breakfast consumption among New Zealand children: Associations with body mass index and related nutrition behaviors. Journal of American Dietetic Association, 107 (4), 570-576

20. Wayon, D. P., Haines, O. G. and Crawley, C., (1997). An experimental study of the effects of energy intake at breakfast on test performance of 10 years children in school. International journal of food science and nutrition, 48(1), 5 - 12

\section{APPENDICES}

Table 1: Contribution of Breakfast to Nutrient Intake of Preschool Children N=120

\begin{tabular}{|l|c|c|c|c|}
\hline Nutrients/Day & Rural (N=60) & Urban (N=60) & One-Third RDA & One-Fourth RDA \\
\hline \multicolumn{5}{|c|}{ Major Nutrients (g) } \\
\hline Energy (kcal) & $253 \pm 107.89$ & $247 \pm 111.60$ & 450 & 337 \\
\hline Protein & $5.25 \pm 2.09$ & $5.56 \pm 2.31$ & 6.7 & 5.02 \\
\hline Visible fat & $6.12 \pm 2.64$ & $6.12 \pm 2.88$ & 8.34 & 6.25 \\
\hline Fiber & $2.18 \pm 1.29$ & $1.77 \pm 1.26$ & - & - \\
\hline Carbohydrate & $43.72 \pm 20.14$ & $42.08 \pm 22.51$ & - & - \\
\hline \multicolumn{5}{|c|}{ Minerals (mg) } \\
\hline Calcium & $41.50 \pm 11.89$ & $57.51 \pm 29.65$ & 200 & 150 \\
\hline Iron & $3.92 \pm 5.60$ & $2.74 \pm 5.07$ & 4.34 & 3.25 \\
\hline Sodium & $43.51 \pm 34.19$ & $95.49 \pm 87.28$ & - & - \\
\hline Potassium & $107.33 \pm 60.11$ & $95.29 \pm 49.11$ & - & 1.75 \\
\hline Zinc & $0.30 \pm 1.16$ & $0.07 \pm 0.23$ & 2.34 & 17.5 \\
\hline Magnesium & $31.48 \pm 38.96$ & $17.90 \pm 35.31$ & 23.34 & \\
\hline
\end{tabular}




\begin{tabular}{|l|c|c|c|c|}
\hline \multicolumn{5}{|c|}{ Table 1: Contd., } \\
\hline Copper & $0.15 \pm 0.31$ & $0.06 \pm 0.31$ & - & - \\
\hline \multicolumn{5}{|c|}{ Vitamins (mg) } \\
\hline B carotene $(\mu \mathrm{g})$ & $29.45 \pm 13.20$ & $42.17 \pm 59.82$ & 1066.67 & 800 \\
\hline Thiamine & $0.16 \pm 0.09$ & $0.15 \pm 0.07$ & 0.24 & 0.17 \\
\hline Riboflavin & $0.10 \pm 0.03$ & $0.11 \pm 0.05$ & 0.27 & 0.20 \\
\hline Niacin & $1.43 \pm 1.14$ & $1.06 \pm 1.06$ & 3.67 & 2.75 \\
\hline Folic acid $(\mu \mathrm{g})$ & $5.49 \pm 6.46$ & $5.20 \pm 7.63$ & 33.34 & 25 \\
\hline Ascorbic acid & $2.24 \pm 1.26$ & $1.62 \pm 1.31$ & 13.34 & 10 \\
\hline Pyridoxine & $0.01 \pm 0.03$ & $0.00 \pm 0.02$ & 0.30 & 0.22 \\
\hline
\end{tabular}

RDA- Recommended Dietary Allowances, ICMR (2010)

Table 2: Food Consumption of Preschool Children as Influenced by Breakfast Pattern N=120

\begin{tabular}{|c|c|c|c|c|}
\hline \multirow[b]{2}{*}{ Foods (G) } & \multirow[b]{2}{*}{ SBD $^{¥}$} & \multirow[b]{2}{*}{ Breakfast Consumers $(\mathrm{N}=94)$} & \multirow[b]{2}{*}{ Breakfast Skippers $(\mathrm{N}=\mathbf{2 6})$} & 'T' Value \\
\hline & & & & $\begin{array}{c}\text { Breakfast Consumers } \\
\text { and Skippers }\end{array}$ \\
\hline Cereals & 120 & $107.70 \pm 26.93$ & $109.23 \pm 24.07$ & $0.26^{\mathrm{NS}}$ \\
\hline Pulses & 30 & $14.76 \pm 7.46$ & $8.66 \pm 6.56$ & $3.70 * *$ \\
\hline Other vegetables & 100 & $35.27 \pm 10.68$ & $35.77 \pm 10.17$ & $0.82^{\mathrm{NS}}$ \\
\hline Fruits & 100 & $30.43 \pm 30.35$ & 0.00 & $5.09^{* * *}$ \\
\hline Milk (ml) & 500 & $102.09 \pm 86.26$ & $67.69 \pm 62.30$ & $1.89^{\mathrm{NS}}$ \\
\hline Visible fat & 25 & $7.66 \pm 2.67$ & $11.50 \pm 6.73$ & $4.45 * *$ \\
\hline Sugar & 20 & $9.43 \pm 4.78$ & $7.69 \pm 5.34$ & $1.60^{\mathrm{NS}}$ \\
\hline Egg & 50 & $17.34 \pm 21.80$ & $27.69 \pm 23.37$ & $2.10 *$ \\
\hline Nuts and oil seeds & - & $15.16 \pm 9.98$ & $19.23 \pm 9.56$ & $1.85^{\mathrm{NS}}$ \\
\hline
\end{tabular}

Dietary guidelines for Indians A manual, NIN, (2011), ¥ SBD - Suggested Balance Diet,

Table 3: Breakfast Consumption Pattern as Influenced by Daily Nutrient Intake $\mathbf{N = 1 2 0}$

\begin{tabular}{|c|c|c|c|c|c|c|c|}
\hline Nutrients & $\mathbf{R D A}^{¥}$ & $\begin{array}{c}\text { Always } \\
\text { Consumers } \\
(\mathrm{N}=62)\end{array}$ & $\begin{array}{c}\text { Often } \\
\text { Consumers } \\
(\mathrm{N}=32)\end{array}$ & $\begin{array}{l}\text { Sometime } \\
\text { Consumers } \\
(\mathrm{N}=10)\end{array}$ & $\begin{array}{c}\text { Rarely } \\
\text { Consumers } \\
(\mathbf{N}=16)\end{array}$ & SEM & CD \\
\hline \multicolumn{8}{|c|}{ Major Nutrients } \\
\hline Energy (kcal) & 1350 & $825 \pm 185.94$ & $788 \pm 143.97$ & $825 \pm 153.30$ & $832 \pm 186.98$ & 0.03 & NS \\
\hline $\operatorname{Protein}(\mathrm{g})$ & 20.1 & $19.82 \pm 5.11^{\mathrm{a}}$ & $18.00 \pm 4.70^{\mathrm{ab}}$ & $16.79 \pm 4.33^{\mathrm{ab}}$ & $15.36 \pm 3.85^{b}$ & 0.0027 & $0.008 *$ \\
\hline Visible fat $(\mathrm{g})$ & 25 & $16.37 \pm 4.92^{b}$ & $16.07 \pm 4.41^{\mathrm{b}}$ & $17.99 \pm 5.42^{\mathrm{ab}}$ & $20.53 \pm 5.87^{\mathrm{a}}$ & 0.0027 & $0.008^{*}$ \\
\hline Fiber $(\mathrm{g})$ & - & $9.08 \pm 2.63$ & $8.55 \pm 2.18$ & $8.50 \pm 1.93$ & $7.66 \pm 2.03$ & 0.003 & NS \\
\hline Carbohydrate (g) & - & $149.86 \pm 35.07$ & $\begin{array}{l}142.62 \pm \\
28.46\end{array}$ & $142.55 \pm 28.49$ & $139.53 \pm 35.04$ & 0.014 & NS \\
\hline \multicolumn{8}{|c|}{ Minerals (mg) } \\
\hline Calcium & 600 & $140.80 \pm 74.40$ & $\begin{array}{l}135.51 \pm \\
58.06\end{array}$ & $127.80 \pm 38.32$ & $122.58 \pm 34.30$ & 0.02 & NS \\
\hline Iron & 13 & $9.10 \pm 6.56$ & $7.27 \pm 5.03$ & $5.24 \pm 1.34$ & $6.24 \pm 4.61$ & 0.006 & NS \\
\hline Sodium & - & $99.85 \pm 50.83^{b}$ & $\begin{array}{l}129.83 \pm \\
80.00^{\mathrm{ab}}\end{array}$ & $\begin{array}{l}185.26 \pm \\
101.57^{\mathrm{a}}\end{array}$ & $\begin{array}{l}175.58 \pm \\
120.99^{\mathrm{a}}\end{array}$ & 0.023 & $0.08 * *$ \\
\hline Potassium & - & $396.05 \pm 149.41$ & $\begin{array}{l}357.36 \pm \\
128.94\end{array}$ & $327.20 \pm 60.03$ & $\begin{array}{l}372.58 \pm \\
136.05\end{array}$ & 0.029 & NS \\
\hline Magnesium & 70 & $206.10 \pm 72.75$ & $\begin{array}{l}186.09 \pm \\
63.73\end{array}$ & $193.83 \pm 58.35$ & $174.96 \pm 58.90$ & 0.02 & NS \\
\hline Zinc & 7 & $2.23 \pm 1.31$ & $1.84 \pm 0.73$ & $1.98 \pm 0.60$ & $1.70 \pm 0.49$ & 0.003 & $\mathrm{NS}$ \\
\hline Copper & - & $0.83 \pm 0.97$ & $0.60 \pm 0.60$ & $0.48 \pm 0.11$ & $0.49 \pm 0.23$ & 0.002 & $\mathrm{NS}$ \\
\hline \multicolumn{8}{|c|}{ Vitamins } \\
\hline$\beta$ carotene $(\mu \mathrm{g})$ & 3200 & $113.37 \pm 80.58$ & $\begin{array}{l}138.84 \pm \\
117.55\end{array}$ & $\begin{array}{l}186.20 \pm \\
146.14\end{array}$ & $113.13 \pm 77.10$ & 0.025 & NS \\
\hline Thiamine (mg) & 0.7 & $0.74 \pm 0.29$ & $0.74 \pm 0.26$ & $0.73 \pm 0.15$ & $0.79 \pm 0.36$ & 0.00 & NS \\
\hline Riboflavin (mg) & 0.8 & $0.36 \pm 0.11$ & $0.37 \pm 0.11$ & $0.42 \pm 0.11$ & $0.40 \pm 1.15$ & 0.001 & $\mathrm{NS}$ \\
\hline Niacin (mg) & 11 & $6.44 \pm 2.26$ & $5.70 \pm 1.76$ & $5.53 \pm 5.25$ & $5.45 \pm 1.55$ & 0.004 & $\mathrm{NS}$ \\
\hline
\end{tabular}




\begin{tabular}{|l|l|l|l|l|l|l|l|}
\hline \multicolumn{2}{|c|}{ Table 3: Contd., } \\
\hline Folic acid $(\mu \mathrm{g})$ & 100 & $37.39 \pm 14.94$ & $32.85 \pm 15.48$ & $38.66 \pm 18.55$ & $31.59 \pm 9.89$ & 0.01 & NS \\
\hline $\begin{array}{l}\text { Ascorbic acid } \\
(\mathrm{mg})\end{array}$ & 40 & $6.95 \pm 4.19$ & $6.42 \pm 3.96$ & $5.08 \pm 1.90$ & $4.64 \pm 2.60$ & 0.004 & NS \\
\hline Pyridoxine $(\mathrm{mg})$ & 0.9 & $0.07 \pm 0.05$ & $0.06 \pm 0.06$ & $0.07 \pm 0.05$ & $0.07 \pm 0.05$ & 0.0006 & NS \\
\hline
\end{tabular}

1-Always (6-7 days /week), 2-Often (4-5 days/week), 3-Sometimes (2-3 days/week), 4-Rarely (0-1 day/week), MUAC-

Mid Upper Arm Circumference

$¥$ Recommended Dietary Allowances (RDA), ICMR, 2010

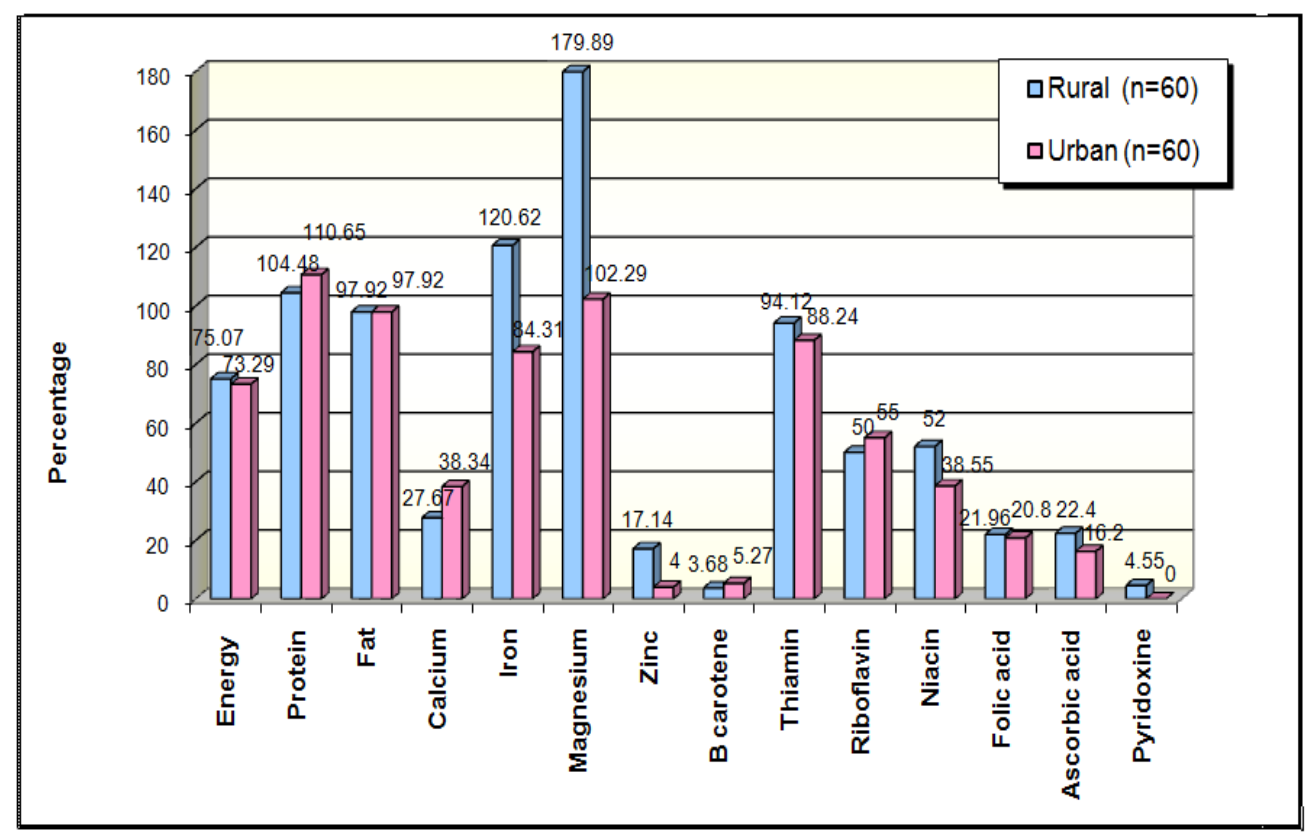

Figure 1: Adequacy of One Fourth Contribution of Nutrients by the Breakfast 
